\title{
Effect of Beverage Industry Effluent Irrigation Growth, Yield and Quality of Sunflower
}

\author{
T.S. Punith Raj ${ }^{*}$, C.A. Srinivasamurthy ${ }^{2}$, S. Bhaskar $^{3}$, S. S. Prakash ${ }^{4}$, \\ and Prabhudev Dhumgond ${ }^{4}$
}

\author{
${ }^{1}$ CGWB, Ministry of Water Resources, Govt. of India, Bhubaneswar, Orissa-751030, India \\ ${ }^{2}$ Central Agricultural University, Imphal, India \\ ${ }^{3}$ Agronomy, Agro-Forestry and Climate change, ICAR, New Delhi, India \\ ${ }^{4}$ Department of Soil Science and Agricultural Chemistry, CoA, Mandya, India \\ *Corresponding author
}

\section{A B S T R A C T}

\section{Keywords \\ Beverage industry, Effluent irrigation, Quality of sunflower}

\section{Article Info}

Accepted:

20 March 2017

Available Online:

10 April 2017
A field experiment was conducted in the premises of Pepsico Pvt. Ltd., near Bengaluru during 2013-14 to study the effect of beverage industry effluent on growth, yield and quality of sunflower with ten treatments replicated thrice using RCBD design. The beverage industry effluent was neutral in reaction, medium in electrical conductivity (1.59 $\left.\mathrm{dSm}^{-1}\right)$, BOD $\left(42.2 \mathrm{mg} \mathrm{L}^{-1}\right)$ and COD $\left(143 \mathrm{mg} \mathrm{L}^{-1}\right)$ but low in plant nutrients content. Among the treatments, growth parameters like plant height, head diameter and number of leaves (184.5, $16.1 \mathrm{~cm}$ and 32.1, respectively) were significantly higher in treatment $\mathrm{T}_{10}$ at 60 DAS. Significantly higher dry matter production in leaf, stem, ear head and TDM were observed in $\mathrm{T}_{10}$. Significant increase in yield attributes such as total dry matter, head weight, kernel weight per head, number of grains per head, grain filling per cent, test weight and volume weight were observed in $\mathrm{T}_{10}$. Oil content and oil yield of sunflower crop varied significantly due to treatments. Fatty acids such as palmitic, stearic, oleic and linoleic acid did not differ significantly due to beverage industry effluent irrigation. Treatment $\mathrm{T}_{10}$ recorded significantly higher grain $\left(3.43 \mathrm{tha}^{-1}\right)$ and stalk yield $\left(4.99 \mathrm{t} \mathrm{ha}^{-1}\right)$ compared to other treatments. Significantly lower grain $\left(1.83 \mathrm{t} \mathrm{ha}^{-1}\right)$ and stalk yield $(2.67 \mathrm{t}$ $\mathrm{ha}^{-1}$ ) were recorded in $\mathrm{T}_{2}$.

\section{Introduction}

Water and nutrients are the most important natural resources for crop production and their management is more challenging due to their scarcity and high cost. Their efficient use is indispensable for the sustainable agriculture in view of shrinking land and water resources and increasing prices of fertilizer, haunting energy crisis, wide spread pollution and fast depletion of natural resources. The rapid increase in population and demand for industrial establishments to meet human requirements has created problems such as overexploitation of available resources, leading to pollution of land, air and water. By 2020 AD in India is required to produce about $300 \mathrm{mt}$ of food grains to feed the ever growing population.

Population growth with increasing urbanization and industrialization is 
encroaching upon the share of agricultural water and is leading to production of huge quantities of waste water, which are beyond the capacity of natural systems to assimilate. Majority of the industries in India consume large volume of fresh water and discharge the entire quantity of water as effluent loaded with pollutants. Pollution of soil and water bodies is a serious problem ever since man started disposing sewage and industrial effluents into water bodies and on land. Indiscriminate discharge of this waste water on soil and into water bodies may create serious problems of pollution. Thus, there is a need to develop eco-friendly measures to exploit the liquid wastes profitably.

The Pepsico beverage industry is one of the largest users of water. Even though substantial technological improvements have been made, beverage industry has been producing approximately 650-700 KLD (Kilo litres per day) of effluent. These effluents are produced during different process such as RO reject (135-150 KLD), equipment sanitation (130-150 KLD), final bottle washing (70-80 KLD), floor cleaning (40-50 KLD), filter backwash (120-130 KLD) and domestic activities (15-25 KLD).

Agricultural use of treated waste water, therefore, might represent a unique opportunity to solve both the problems of water supply for irrigation and disposal of treated waste water at the same time. In developing countries, non-utilization of these effluents has its impact on economic growth and development and there is increased recognition for this potential.

Due to increasing environmental concerns and regulations, there have been attempts to utilize this beverage industry effluent in an eco-friendly manner.

Sunflower globally ranks second to soybean among annual field crops grown for edible oil. The quantity of sunflower oil represents about 15 per cent of the total world production of the major vegetable oils. In India, it occupies an area of $1.81 \mathrm{~m}$ ha with a production of $1.16 \mathrm{mt}$ and productivity of 639 $\mathrm{kg} \mathrm{ha}^{-1}$ (Anon., 2012). In Karnataka, it is grown over an area of $1 \mathrm{~m}$ ha with a production of $0.49 \mathrm{~m} \mathrm{t}$ and the average productivity is $496 \mathrm{~kg} \mathrm{ha}^{-1}$ (Anon., 2010). Karnataka stands first with respect to area and production of sunflower in India. But the average productivity is below the national average.

The characteristics of industrial effluents profoundly vary and are determined by type of product, nature of inputs involved, effluent treatment processes and capacity of industrial unit. Reuse of this water is always associated with advantages and disadvantages.

Apart from supplying water, its organic and inorganic constituents could meet nutrients requirement of crops, decrease the fertilizer/manure requirement, improve soil fertility and simultaneously enhances the chances of contaminating soil, water and producing degraded quality crops (Qadir and Schubert, 2002). Use of effluent successfully involves questions concerning safe protocol of its use for crops, impact of its use on growth, yield of crops and soil properties. So, the research on successful and productive use of beverage industry effluent on crops is scanty. Hence, this study was taken up to standardize the practices of its safe usage in agriculture.

\section{Materials and Methods}

Nelamangala is located in Banglore rural district of Eastern Dry Zone, Karnataka and situated at $12^{\circ} 11^{\prime}$ North latitude $76^{\circ} 69^{\prime}$ East longitude with an altitude of 610 meters above mean sea level. A field experiment was carried out during 2013-14 with 10 different 
treatments as given in table 1, to know the effect of beverage industry effluent on growth, yield and quality of sunflower. Sunflower crop was grown in plots of $3.6 \times 3$ $\mathrm{m}^{2}$ size with 3 replications using RCBD design. Beverage industry effluent was collected at 60 days interval from Pepsico Pvt. Ltd., and the samples were analyzed for $\mathrm{pH}$, electrical conductivity, BOD, COD, total solids, total suspended solids, total dissolved solids, total nitrogen, phosphorus, potassium, sodium, calcium, magnesium, chlorides, sulphates and micronutrients $(\mathrm{Zn}, \mathrm{Cu}, \mathrm{Fe}, \mathrm{Mn}$ and B) content by following standard procedures and the average values are presented in table 2 . The calculated quantities of nutrients were added as per recommendations.

The quantity of gypsum was calculated on the equivalent basis of sodium $\left(\mathrm{Na}^{+}\right)$content of beverage industry effluent $\left(10.3 \mathrm{~m} . \mathrm{eq} \mathrm{L}^{-1}\right)$ and fresh irrigation water $\left(3.35 \mathrm{~m} . \mathrm{eq} \mathrm{L}^{-1}\right)$. It was applied as basal dose to the treatments $\mathrm{T}_{6}$ to $\mathrm{T}_{10}$ to study the possibilities of overcoming the adverse effect of sodium present in effluent on soil properties. The experiment received 50 per cent of the gypsum required. Based on the irrigation requirement of sunflower $(\approx 5$ irrigations @ $@ 5$ cm/irrigation $)$ the treatments received cycles of irrigation with fresh water and beverage industry effluent.

The crop was irrigated with fresh water for first 15 days after sowing to avoid the deleterious effect if any of high sodium content of the beverage industry effluent on initial establishment of plants. After 15 days, the crops were imposed with the irrigation treatments as detailed in table 1. The standard analytical procedures were adopted for soil analysis. The initial soil properties of the experimental site are $\mathrm{pH}$ (7.95), EC (0.53 $\mathrm{dS} / \mathrm{m})$, OC (4.6 g/kg), avail-N (189.6 kg/ha), $\mathrm{P}(26.9 \mathrm{~kg} / \mathrm{ha})$ and $\mathrm{K}(218.8 \mathrm{~kg} / \mathrm{ha})$.

\section{Results and Discussion}

\section{Growth parameters}

The results revealed that growth and yield parameters of sunflower crop differed significantly due to irrigation with beverage industry effluent and gypsum (Table 3 ).

Plant height: Significantly higher plant height during 30, 60 and 90 DAS and at harvest $(84.4,184.5224 .7$ and $227.9 \mathrm{~cm}$, respectively) was observed with cycle of 1 irrigation with fresh water +2 irrigations with beverage industry effluent $+\mathrm{RDF}+$ gypsum $\left(\mathrm{T}_{10}\right)$ compared to all other treatments followed by irrigation with beverage industry effluent $+\mathrm{RDF}+$ gypsum $\left(\mathrm{T}_{7}\right)(83,183.2$, 223.4 and $225.8 \mathrm{~cm}$, respectively) and irrigation with fresh water + RDF with gypsum $\left(\mathrm{T}_{6}\right)(82,182.2,222.4$ and $226.7 \mathrm{~cm}$, respectively). The treatments $\mathrm{T}_{3}, \mathrm{~T}_{1}$ (73.3, 173.4, 213.5, $215.9 \mathrm{~cm}$ and 76.2, 176.3, 216, $221.4 \mathrm{~cm}$, respectively) and $\mathrm{T}_{8}, \mathrm{~T}_{9}(78.3$, 178.6, 218.8, 223.1 cm and 79.4, 179.7, $219.6,225.3 \mathrm{~cm}$, respectively) were found to be on par with each other. However, significantly lower plant height during all the stages of crop growth $(61.2,161.4,201.6$ and $205.6 \mathrm{~cm}$, respectively) was observed in the treatment $\mathrm{T}_{2}$ receiving irrigation with beverage industry effluent + RDF without gypsum.

\section{Number of leaves}

During different growth stages $(30,60,90$ DAS and at harvest) of sunflower, significant difference with respect to number of leaves due to beverage industry effluent irrigation was observed. Significantly higher number of leaves was observed with cycle of 1irrigation with fresh water +2 irrigations with beverage industry effluent + RDF + gypsum $\left(\mathrm{T}_{10}\right)$ compared to all other treatments. Significantly lower number of leaves during 
all the stages of crop growth $(4.2,21.9,12.1$ and 8.6, respectively) was observed in the treatment $\mathrm{T}_{2}$ receiving irrigation with beverage industry effluent + RDF without gypsum.

\section{Head diameter}

Significantly higher head diameter was observed during 60, 90 DAS and at harvest (16.1, 26.4 and $31.6 \mathrm{~cm}$, respectively) with cycle of 1 irrigation with fresh water +2 irrigations with beverage industry effluent + $\mathrm{RDF}+$ gypsum $\left(\mathrm{T}_{10}\right)$ compared to all other treatments followed by irrigation with beverage industry effluent + RDF + gypsum $\left(\mathrm{T}_{7}\right)$ (186.2 and 252.2, respectively) and irrigation with fresh water + RDF with gypsum $\left(\mathrm{T}_{6}\right)(15.6,24.7$ and $30.2 \mathrm{~cm}$, respectively). The treatments $\mathrm{T}_{3}, \mathrm{~T}_{4}(11,21.1$, $21.6 \mathrm{~cm}$ and 11.1, 21.1, 22.5, respectively) and $\mathrm{T}_{8}, \mathrm{~T}_{9}(13.1,23.1,26.8 \mathrm{~cm}$ and 13, 23.1, $24 \mathrm{~cm}$, respectively) were found to be on par with each other. However, significantly lower head diameter at 60, 90 DAS and at harvest (8.1, 18.2 and $19.2 \mathrm{~cm}$, respectively) was observed in the treatment $\mathrm{T}_{2}$ receiving irrigation with beverage industry effluent + RDF without gypsum.

\section{Total dry matter accumulation}

The data on total dry matter accumulation and yield parameters such as head weight, kernel weight per head, number of grains per head, grain filling per cent, test weight and volume weight varied significantly due to beverage industry effluent irrigation at harvest. Significantly higher total dry matter production was observed in the treatment receiving cycle of 1 irrigation with fresh water +2 irrigations with beverage industry effluent + RDF + gypsum $\left(\mathrm{T}_{10}: 180.2 \mathrm{~g}\right.$ plant $\left.{ }^{1}\right)$ compared to all the other treatments followed by irrigation with fresh water $+\mathrm{RDF}$ + gypsum $\left(\mathrm{T}_{6}: 177.4 \mathrm{~g}_{\text {plant }}{ }^{-1}\right)$ and was on par with $\mathrm{T}_{7}$. Significantly lower total dry matter production was observed in the treatment with irrigation of beverage industry effluent + RDF without gypsum $\left(\mathrm{T}_{2}\right.$ : $\left.105.2 \mathrm{~g} \mathrm{plant}^{-1}\right)$.

\section{Yield and yield parameters}

The data pertaining to yield parameters such as head weight, kernel weight per head, number of grains per head, grain filling percent, test weight and volume weight of sunflower crop as influenced by beverage industry effluent irrigation are presented in table 4 .

Different irrigation treatments with gypsum and without gypsum showed a profound effect in increasing the head weight and kernel weight per head. Maximum head and kernel weight was recorded in the treatment which received cycle of 1 irrigation with fresh water +2 irrigations with beverage industry effluent + RDF + gypsum $(1.73 \mathrm{~kg}$ and 72.3 $\mathrm{g}$, respectively) followed by irrigation with beverage industry effluent + RDF + gypsum $\left(\mathrm{T}_{7}: 1.61 \mathrm{~kg}\right.$ and $67.4 \mathrm{~g}$, respectively) and irrigation with fresh water + RDF with gypsum ( $\mathrm{T}_{6}: 1.55 \mathrm{~kg}$ and $64.7 \mathrm{~g}$, respectively) and significantly superior over the treatment with irrigation of beverage industry effluent + RDF without gypsum $\left(\mathrm{T}_{2}: 0.92 \mathrm{~kg}\right.$ and $38.4 \mathrm{~g}$, respectively).

Number of grains per head and grain filling percent increased significantly with cycle of 1 irrigation with fresh water +2 irrigations with beverage industry effluent + RDF + gypsum $\left(\mathrm{T}_{10}: 1320\right.$ and $95.3 \%$, respectively) compared to all other treatments. Significantly lower number of grains and grain filling percent was recorded in the treatment which received irrigation of beverage industry effluent + RDF without gypsum ( $\mathrm{T}_{2}: 696$ and $83.1 \%$, respectively).

Treatments differed significantly due to irrigation with fresh water, beverage industry effluent and application of gypsum. 
Significantly higher test weight and volume weight was observed in the treatment receiving cycle of 1 irrigation with fresh water +2 irrigations with beverage industry effluent $+\mathrm{RDF}+$ gypsum $\left(\mathrm{T}_{10}: 6.75\right.$ and 66.4 g) followed by irrigation with beverage industry effluent + RDF + gypsum $\left(\mathrm{T}_{7}: 6.3\right.$ and $61.8 \mathrm{~g}$, respectively) and was on par with $\mathrm{T}_{6}$ (6.24 and $59.4 \mathrm{~g}$, respectively). However, significantly lower test weight and volume weight were recorded in the treatment $T_{2}$ which received irrigation of beverage industry effluent + RDF without gypsum (3.59 and $35.2 \mathrm{~g}$, respectively).

The data pertaining to grain yield, stalk yield, oil content and oil yield of sunflower crop as influenced by beverage industry effluent irrigation are presented in table 5.

Cycle of 1 irrigation with fresh water +2 irrigations with beverage industry effluent + $\mathrm{RDF}+$ gypsum $\left(\mathrm{T}_{10}\right)$ recorded significantly higher grain and stalk yield (3.43 and $4.99 \mathrm{t}$ $\mathrm{ha}^{-1}$, respectively) compared to all other treatments followed by the irrigation with beverage industry effluent $+\mathrm{RDF}+$ gypsum $\left(\mathrm{T}_{7}\right)$ (3.2 and $4.7 \mathrm{t} \mathrm{ha}^{-1}$, respectively) and irrigation with fresh water $+\mathrm{RDF}$ with gypsum $\left(\mathrm{T}_{6}\right) \quad\left(3.08\right.$ and $4.51 \mathrm{t} \quad \mathrm{ha}^{-1}$, respectively). The treatments $\mathrm{T}_{3}$ and $\mathrm{T}_{5}(2.14$, $3.14 \mathrm{t} \mathrm{ha}^{-1}$ and 2.0, $2.92 \mathrm{t} \mathrm{ha}^{-1}$, respectively) were found to be on par with each other. Significantly lower grain and straw yield (1.83 and $2.67 \mathrm{t} \mathrm{ha}^{-1}$, respectively) was recorded in the treatment receiving irrigation with beverage industry effluent $+\mathrm{RDF}$ without gypsum $\left(\mathrm{T}_{2}\right)$.

Oil content and oil yield of sunflower crop varied significantly due to treatments. Significantly higher oil content $(40.8 \%)$ was recorded in the treatment $\mathrm{T}_{9}$ receiving cycle of 2 irrigations with fresh water +1 irrigation with beverage industry effluent + RDF + gypsum followed by $T_{7}$ and $T_{10}$ (40.3 and
$40.2 \%$, respectively) and were on par with each other (Table 5). Maximum oil yield was observed in the treatment $T_{10}$ which received cycle of 1 irrigation with fresh water +2 irrigations with beverage industry effluent + $\mathrm{RDF}+$ gypsum $\left(1377.3 \mathrm{Kg} \mathrm{ha}^{-1}\right)$ followed by $\mathrm{T}_{7}$ and $\mathrm{T}_{6}$ (1288.4 and $1200.7 \mathrm{Kg} \mathrm{ha}^{-1}$, respectively). However, lowest oil content and oil yield was observed in the treatment $T_{2}$ receiving irrigation with beverage industry effluent + RDF without gypsum $\left(704.6 \mathrm{Kg}^{-}\right.$ 1 , respectively).

\section{Fatty acid profile}

The data pertaining to different fatty acids content of sunflower oil as influenced by beverage industry effluent irrigation are presented in table 6. Fatty acids such as palmitic, stearic, oleic and linoleic acid did not differ significantly due to beverage industry effluent irrigation. However, higher per cent of palmitic acid was recorded in the treatment $\mathrm{T}_{10}(6.79 \%)$ and lower value was in treatment $\mathrm{T}_{7}(5.39 \%)$. Further, stearic acid content was highest in the treatment $\mathrm{T}_{7}$ (3.62 $\%)$ and was lowest in the treatment $\mathrm{T}_{10}(2.97$ $\%)$. Oleic and linoleic acid content was higher in the treatment $\mathrm{T}_{8}$ and $\mathrm{T}_{3}(50.4$ and $52.7 \%)$ but the lower content was recorded in the the treatment $\mathrm{T}_{3}$ and $\mathrm{T}_{8}(37.8$ and $40.8 \%)$.

\section{Growth, yield parameters and yield of sunflower}

The results revealed that growth, yield parameters and yield of sunflower crop differed significantly due to irrigation with beverage industry effluent and gypsum (Table 3 to 5). However, significantly higher plant height, number of leaves and head diameter was observed in the treatment $\mathrm{T}_{10}$ compared to all other treatments followed by $\mathrm{T}_{7}$ and $\mathrm{T}_{6}$. This might be due to addition of small amount of nutrients from beverage industry effluent and gypsum as an amendment which are 
required for plant growth and development. This increased plant growth attributes may be due to plant growth influencing material such as auxin, amino acids, vitamins that are influenced by $\mathrm{S}$ application (Imayavaramban et al., 2002 and Ahmad and Jabeen, 2009).

Significant increase in yield attributes such as total dry matter, head weight, kernel weight per head, number of grains per head, grain filling per cent, test weight and volume weight were observed in $\mathrm{T}_{10}$ compared to all other treatments followed by $\mathrm{T}_{7}$ and $\mathrm{T}_{6}$. This could be due to addition of small amount of nutrients through effluent and gypsum, full exposure of head encouraged better photosynthesis, better pollination by the insects, better utilization of more photosynthates from protein and less fat synthesis coupled with FYM and S application (Vaiyapuri et al., 2004).
Significant increase in grain and stalk yield of sunflower in treatment $\mathrm{T}_{10}$ (3.43 and $4.99 \mathrm{t}$ ha 1 , respectively) compared to all other treatments followed by $\mathrm{T}_{7}\left(3.2\right.$ and $4.7 \mathrm{t} \mathrm{ha}^{-1}$, respectively) and $\mathrm{T}_{6}$ (3.08 and $4.51 \mathrm{t} \mathrm{ha}^{-1}$, respectively). Similar results were recorded by Dhananjaya (2005), Vijay Krishna (2005) and Basavalingaiah et al., (2009a) who found that alternate irrigation with fresh water and lime treated coffee pulp effluent recorded higher fodder yield (35.2 $\left.\mathrm{t} \mathrm{ha}^{-1}\right)$, which was on par with 2:1 cycles of lime treated coffee pulp effluent and fresh water $\left(33.3 \mathrm{t} \mathrm{ha}^{-1}\right)$. The enhanced values of yield attributing characters were witnessed due to tendency of nutrients in accelerating growth, photosynthetic activity and translocation efficiency of photosynthates towards the reproductive sink (Ujjinaiah et al., 1995, Reddy and Kumar, 1996 and Yadav et al., 2010).

Table.1 Treatment details

\begin{tabular}{|c|c|}
\hline $\mathbf{T}_{1}$ & Irrigation with fresh water + RDF without gypsum \\
\hline $\mathbf{T}_{2}$ & $\begin{array}{l}\text { Irrigation with beverage industry effluent }+ \text { RDF without } \\
\text { gypsum }\end{array}$ \\
\hline $\mathbf{T}_{3}$ & $\begin{array}{l}\text { Alternate irrigation with fresh water and beverage } \\
\text { industry effluent }+ \text { RDF without gypsum }\end{array}$ \\
\hline $\mathbf{T}_{4}$ & $\begin{array}{l}\text { Cycle of } 2 \text { irrigations with fresh water }+1 \text { irrigation with } \\
\text { beverage industry effluent }+\mathrm{RDF} \text { without gypsum }\end{array}$ \\
\hline $\mathbf{T}_{5}$ & $\begin{array}{l}\text { Cycle of } 1 \text { irrigation with fresh water }+2 \text { irrigations with } \\
\text { beverage industry effluent }+ \text { RDF without gypsum }\end{array}$ \\
\hline $\mathbf{T}_{6}$ & Irrigation with fresh water + RDF + gypsum \\
\hline $\mathbf{T}_{7}$ & $\begin{array}{l}\text { Alternate irrigation with fresh water and beverage } \\
\text { industry effluent + RDF + gypsum }\end{array}$ \\
\hline $\mathbf{T}_{8}$ & $\begin{array}{l}\text { Cycle of } 2 \text { irrigations with fresh water }+1 \text { irrigation with } \\
\text { beverage industry effluent }+ \text { RDF }+ \text { gypsum }\end{array}$ \\
\hline $\mathbf{T}_{9}$ & $\begin{array}{l}\text { Irrigation with beverage industry effluent }+ \text { RDF }+ \\
\text { gypsum }\end{array}$ \\
\hline $\mathbf{T}_{10}$ & $\begin{array}{l}\text { Cycle of lirrigation with fresh water }+2 \text { irrigations with } \\
\text { beverage industry effluent }+\mathrm{RDF}+\text { gypsum }\end{array}$ \\
\hline
\end{tabular}


Table.2 Physico-chemical properties of effluent samples

\begin{tabular}{|c|c|c|c|c|c|c|c|c|c|c|c|}
\hline Parameters & Sample-1 & Sample-2 & Sample-3 & Sample-4 & Sample-5 & Sample-6 & Sample-7 & Sample-8 & Sample-9 & Sample-10 & Average \\
\hline $\mathrm{pH}$ & 7.55 & 7.49 & 7.60 & 7.35 & 7.65 & 7.42 & 7.71 & 7.58 & 7.68 & 7.49 & $7.55 \pm 0.1$ \\
\hline $\mathrm{EC}\left(\mathrm{dS} \mathrm{m^{-1 } )}\right.$ & 1.52 & 1.50 & 1.62 & 1.58 & 1.68 & 1.48 & 1.76 & 1.54 & 1.69 & 1.53 & $1.59 \pm 0.1$ \\
\hline BOD $\left(\mathrm{mg} \mathrm{L}^{-1}\right)$ & 46 & 42 & 50 & 39 & 35 & 45 & 36 & 49 & 47 & 33 & $42.2 \pm 6.1$ \\
\hline $\operatorname{COD}\left(\mathrm{mg} \mathrm{L}^{-1}\right)$ & 146 & 149 & 156 & 140 & 145 & 138 & 132 & 150 & 138 & 136 & $143 \pm 7.4$ \\
\hline $\mathrm{DS}\left(\mathrm{g} \mathrm{L}^{-1}\right)$ & 1.75 & 1.91 & 2.0 & 1.86 & 1.95 & 1.72 & 2.10 & 1.92 & 1.95 & 1.98 & $1.91 \pm 0.1$ \\
\hline $\mathrm{TSS}\left(\mathrm{g} \mathrm{L}^{-1}\right)$ & 1.57 & 1.56 & 1.52 & 1.63 & 1.45 & 1.50 & 1.64 & 1.70 & 1.63 & 1.60 & $1.5 \pm 0.1$ \\
\hline $\mathrm{TS}\left(\mathrm{g} \mathrm{L}^{-1}\right)$ & 3.26 & 3.39 & 3.3 & 3.48 & 3.31 & 3.25 & 3.81 & 3.70 & 3.56 & 3.58 & $3.46 \pm 0.2$ \\
\hline $\mathrm{Na}\left(\mathrm{m}\right.$. eq L $\left.\mathrm{L}^{-1}\right)$ & 9.6 & 10.4 & 10.3 & 9.4 & 10.8 & 9.5 & 10.5 & 9.8 & 11.6 & 10.9 & $10.3 \pm 0.7$ \\
\hline $\mathrm{CO}_{3}\left(\mathrm{~m} . \mathrm{eq} \mathrm{L} \mathrm{L}^{-1}\right)$ & nil & nil & nil & nil & nil & nil & nil & nil & nil & Nil & Nil \\
\hline $\mathrm{HCO}_{3}\left(\mathrm{~m}\right.$. eq L $\left.{ }^{-1}\right)$ & 6.9 & 6.4 & 6.6 & 6.8 & 6.7 & 6.7 & 7.1 & 7.0 & 7.2 & 6.9 & $6.8 \pm 0.2$ \\
\hline Total-N (mg L $\left.{ }^{-1}\right)$ & $*$ & $*$ & $*$ & $*$ & $*$ & $*$ & $*$ & $*$ & $*$ & $*$ & $*$ \\
\hline Total-P (mg L $\left.{ }^{-1}\right)$ & 2 & 1.8 & 2.3 & 1.6 & 1.7 & 1.5 & 1.9 & 2.1 & 2.3 & 2.8 & $2.0 \pm 0.4$ \\
\hline Total-K $\left(\mathrm{mg} \mathrm{L}^{-1}\right)$ & 30 & 31 & 34 & 28 & 35 & 30 & 34 & 25 & 38 & 45 & $33 \pm 5.6$ \\
\hline Total-S (mg L $\left.{ }^{-1}\right)$ & 150 & 152 & 135 & 146 & 132 & 140 & 155 & 138 & 163 & 159 & $147 \pm 10.5$ \\
\hline $\mathrm{Ca}\left(\mathrm{m} . \mathrm{eq} \mathrm{L} \mathrm{L}^{-1}\right)$ & 3.70 & 3.40 & 3.45 & 3.63 & 3.56 & 3.82 & 3.78 & 3.94 & 3.95 & 3.45 & $3.67 \pm 0.2$ \\
\hline $\mathrm{Mg}\left(\mathrm{m} . \mathrm{eq} \mathrm{L} \mathrm{L}^{-1}\right)$ & 2.60 & 2.50 & 2.68 & 2.62 & 2.52 & 2.35 & 2.78 & 2.60 & 2.30 & 2.10 & $2.51 \pm 0.2$ \\
\hline $\mathrm{Cl}\left(\mathrm{m} . \mathrm{eq} \mathrm{L} \mathrm{L}^{-1}\right)$ & 7.7 & 7.5 & 7.6 & 7.3 & 7.0 & 7.2 & 7.4 & 7.5 & 8.9 & 7.8 & $7.5 \pm 0.5$ \\
\hline $\mathrm{Fe}\left(\mathrm{mg} \mathrm{L}^{-1}\right)$ & nil & nil & nil & nil & nil & nil & nil & nil & nil & nil & Nil \\
\hline $\mathrm{Cu}\left(\mathrm{mg} \mathrm{L}^{-1}\right)$ & nil & nil & nil & nil & nil & nil & nil & nil & nil & nil & Nil \\
\hline $\mathrm{Mn}\left(\mathrm{mg} \mathrm{L}^{-1}\right)$ & nil & nil & nil & nil & nil & nil & nil & nil & nil & nil & Nil \\
\hline $\mathrm{Zn}\left(\mathrm{mg} \mathrm{L}^{-1}\right)$ & nil & nil & nil & nil & nil & nil & nil & nil & nil & nil & Nil \\
\hline $\mathrm{B}\left(\mathrm{mg} \mathrm{L}^{-1}\right)$ & nil & nil & nil & nil & nil & nil & nil & nil & nil & nil & Nil \\
\hline SAR & 5.6 & 6.2 & 6.1 & 5.2 & 6.3 & 5.6 & 5.8 & 5.4 & 6.8 & 6.8 & $6.0 \pm 0.6$ \\
\hline $\operatorname{RSC}\left(\right.$ m.eq L $\left.{ }^{-1}\right)$ & 0.60 & 0.50 & 0.47 & 0.55 & 0.64 & 0.53 & 0.54 & 0.46 & 0.95 & 1.35 & $0.66 \pm 0.3$ \\
\hline \multicolumn{12}{|c|}{ Note: $*$ indicates traces found that could not be detected } \\
\hline \multicolumn{12}{|c|}{ Sodium content of fresh water } \\
\hline $\mathrm{Na}\left(\mathrm{m} . \mathrm{eq} \mathrm{L} \mathrm{L}^{-1}\right)$ & 3.3 & 3.5 & 3.0 & 3.2 & 3.5 & 3.1 & 3.7 & 3.4 & 3.3 & 3.0 & $3.3 \pm 0.2$ \\
\hline
\end{tabular}


Table.3 Effect of beverage industry effluent irrigation on plant height, number of leaves and head diameter of sunflower

\begin{tabular}{|c|c|c|c|c|c|c|c|c|c|c|c|}
\hline \multirow[b]{2}{*}{ Treatments } & \multicolumn{4}{|c|}{ Plant height (cm) } & \multicolumn{4}{|c|}{ Number of leaves } & \multicolumn{3}{|c|}{ Head diameter $(\mathrm{cm})$} \\
\hline & 30 DAS & 60 DAS & 90 DAS & $\begin{array}{c}\text { At } \\
\text { harvest }\end{array}$ & 30 DAS & 60 DAS & 90 DAS & $\begin{array}{c}\text { At } \\
\text { harvest }\end{array}$ & 60 DAS & 90 DAS & $\begin{array}{c}\text { At } \\
\text { harvest }\end{array}$ \\
\hline $\mathbf{T}_{1}$ & 76.2 & 176.3 & 216.0 & 221.4 & 7.3 & 28.1 & 18.1 & 11.5 & 12.2 & 22.3 & 25.0 \\
\hline $\mathbf{T}_{2}$ & 61.2 & 161.4 & 201.6 & 205.6 & 4.2 & 21.9 & 12.1 & 8.6 & 8.1 & 18.2 & 19.2 \\
\hline $\mathbf{T}_{\mathbf{3}}$ & 73.3 & 173.4 & 213.5 & 215.9 & 6.2 & 27.9 & 17.9 & 11.8 & 11.0 & 21.1 & 21.6 \\
\hline $\mathbf{T}_{4}$ & 70.3 & 169.9 & 210.5 & 216.5 & 6.1 & 27.2 & 17.2 & 12.4 & 11.1 & 21.1 & 22.5 \\
\hline $\mathbf{T}_{5}$ & 66.4 & 166.6 & 207.0 & 212.2 & 5.0 & 25.0 & 14.8 & 9.7 & 10.1 & 20.2 & 20.8 \\
\hline $\mathbf{T}_{6}$ & 82.0 & 182.2 & 222.4 & 226.7 & 8.9 & 30.1 & 20.1 & 13.3 & 14.0 & 24.1 & 29.0 \\
\hline $\mathbf{T}_{7}$ & 83.0 & 183.2 & 223.4 & 225.8 & 10.0 & 30.9 & 19.6 & 12.5 & 15.6 & 24.7 & 30.2 \\
\hline $\mathbf{T}_{8}$ & 78.3 & 178.6 & 218.8 & 223.1 & 8.1 & 29.1 & 19.7 & 13.4 & 13.1 & 23.1 & 26.8 \\
\hline $\mathbf{T}_{9}$ & 79.4 & 179.7 & 219.6 & 225.3 & 8.5 & 29.1 & 19.8 & 12.9 & 13.0 & 23.1 & 24.0 \\
\hline $\mathbf{T}_{10}$ & 84.4 & 184.5 & 224.7 & 227.9 & 11.8 & 32.1 & 21.1 & 13.1 & 16.1 & 26.4 & 31.6 \\
\hline S. Em \pm & 2.27 & 3.81 & 4.70 & 4.60 & 0.30 & 0.86 & 0.72 & 0.25 & 0.50 & 0.68 & 0.86 \\
\hline C. D. at $5 \%$ & 6.7 & 11.3 & 14.2 & 13.5 & 0.91 & 2.5 & 2.2 & 0.67 & 1.5 & 2.0 & 2.6 \\
\hline CV $(\%)$ & 5.2 & 3.8 & 3.8 & 4.2 & 7.0 & 5.3 & 7.0 & 6.2 & 7.0 & 5.3 & 6.0 \\
\hline
\end{tabular}

\section{Legend:}

$\mathrm{T}_{1}$ : Irrigation with fresh water $+\mathrm{RDF}$ without gypsum

$\mathrm{T}_{2}$ : Irrigation with beverage industry effluent $+\mathrm{RDF}$ without gypsum

$\mathrm{T}_{3}$ : Alternate irrigation with fresh water and beverage industry effluent + RDF without gypsum

$\mathrm{T}_{4}$ : Cycle of 2 irrigations with fresh water +1 irrigation with beverage industry effluent + RDF without gypsum

$\mathrm{T}_{5}$ : Cycle of 1 irrigation with fresh water +2 irrigations with beverage industry effluent + RDF without gypsum
$\mathrm{T}_{6}$ : Irrigation with fresh water $+\mathrm{RDF}+$ gypsum

$\mathrm{T}_{7}$ : Irrigation with beverage industry effluent $+\mathrm{RDF}+$ gypsum

$\mathrm{T}_{8}$ : Alternate irrigation with fresh water and beverage industry effluent $+\mathrm{RDF}+$ gypsum

$\mathrm{T}_{9}$ : Cycle of 2 irrigations with fresh water +1 irrigation with beverage industry effluent + RDF + gypsum

$\mathrm{T}_{10}$ : Cycle of 1 irrigation with fresh water +2 irrigations with beverage industry effluent + RDF + gypsum

FYM@ $9.5 \mathrm{t} \mathrm{ha}^{-1}$ and borax @ $10 \mathrm{~kg} \mathrm{ha}{ }^{-1}$ common for all the treatments 
Table.4 Effect of beverage industry effluent irrigation on total dry matter production, head weight, kernel weight per head, number of grains per head, grain filling per cent, test weight and volume weight of sunflower

\begin{tabular}{|c|c|c|c|c|c|c|c|}
\hline Treatments & $\begin{array}{c}\text { TDM } \\
\left(\text { g plant }^{-1}\right)\end{array}$ & $\begin{array}{c}\text { Head weight } \\
\text { (kg) }\end{array}$ & $\begin{array}{c}\text { Kernel weight } \\
\text { per head (g) }\end{array}$ & $\begin{array}{c}\text { Number of } \\
\text { grains per } \\
\text { head }\end{array}$ & $\begin{array}{l}\text { Grain filling } \\
\text { per cent }\end{array}$ & Test weight (g) & $\begin{array}{l}\text { Volume weight } \\
\text { (g) }\end{array}$ \\
\hline $\mathbf{T}_{1}$ & 152.9 & 1.33 & 55.9 & 1012 & 91.4 & 5.21 & 51.4 \\
\hline $\mathbf{T}_{2}$ & 105.2 & 0.92 & 38.4 & 696 & 83.1 & 3.59 & 35.2 \\
\hline $\mathbf{T}_{\mathbf{3}}$ & 123.6 & 1.07 & 45.1 & 818 & 87.2 & 4.21 & 41.4 \\
\hline $\mathbf{T}_{4}$ & 133.6 & 1.18 & 50.4 & 898 & 89.2 & 4.63 & 45.5 \\
\hline $\mathbf{T}_{5}$ & 115.0 & 1.00 & 42.0 & 761 & 85.6 & 3.92 & 38.5 \\
\hline $\mathbf{T}_{6}$ & 177.4 & 1.55 & 64.7 & 1174 & 93.8 & 6.24 & 59.4 \\
\hline $\mathbf{T}_{7}$ & 176.7 & 1.61 & 67.4 & 1223 & 94.4 & 6.30 & 61.8 \\
\hline $\mathbf{T}_{8}$ & 163.9 & 1.43 & 59.9 & 1084 & 92.6 & 5.58 & 54.9 \\
\hline $\mathbf{T}_{9}$ & 146.8 & 1.26 & 53.6 & 971 & 91.0 & 5.00 & 49.2 \\
\hline $\mathbf{T}_{10}$ & 180.2 & 1.73 & 72.3 & 1320 & 95.3 & 6.75 & 66.4 \\
\hline S. Em \pm & 3.3 & 0.046 & 1.25 & 30.7 & 3.2 & 0.10 & 0.59 \\
\hline C. D. at $5 \%$ & 9.8 & 0.138 & 3.7 & 91.3 & 9.6 & 0.30 & 1.75 \\
\hline CV (\%) & 3.9 & 6.2 & 4.0 & 5.3 & 6.2 & 3.5 & 2.0 \\
\hline
\end{tabular}

\section{Legend:}

$\mathrm{T}_{1}$ : Irrigation with fresh water $+\mathrm{RDF}$ without gypsum

$\mathrm{T}_{2}$ : Irrigation with beverage industry effluent $+\mathrm{RDF}$ without gypsum

$\mathrm{T}_{3}$ : Alternate irrigation with fresh water and beverage industry effluent + RDF without gypsum

$\mathrm{T}_{4}$ : Cycle of 2 irrigations with fresh water +1 irrigation with beverage industry effluent + RDF without gypsum

$\mathrm{T}_{5}$ : Cycle of 1 irrigation with fresh water +2 irrigations with beverage industry effluent + RDF without gypsum
$\mathrm{T}_{6}$ : Irrigation with fresh water $+\mathrm{RDF}+$ gypsum

$\mathrm{T}_{7}$ : Irrigation with beverage industry effluent $+\mathrm{RDF}+$ gypsum

$\mathrm{T}_{8}$ : Alternate irrigation with fresh water and beverage industry effluent $+\mathrm{RDF}+$ gypsum

$\mathrm{T}_{9}$ : Cycle of 2 irrigations with fresh water +1 irrigation with beverage industry effluent + RDF + gypsum

$\mathrm{T}_{10}$ : Cycle of 1 irrigation with fresh water +2 irrigations with beverage industry effluent + RDF + gypsum

FYM@ $9.5 \mathrm{tha}^{-1}$ and borax @ $10 \mathrm{~kg} \mathrm{ha}{ }^{-1}$ common for all the treatments 
Table.5 Effect of beverage industry effluent irrigation on grain yield, stalk yield, oil content and oil yield of sunflower

\section{Legend:}

\begin{tabular}{|c|c|c|c|c|}
\hline \multirow{2}{*}{ Treatments } & \multicolumn{2}{|c|}{ Yield $\left(\mathrm{t} \mathrm{ha}^{-1}\right)$} & \multirow{2}{*}{$\begin{array}{c}\text { Oil content } \\
(\%)\end{array}$} & \multirow{2}{*}{$\begin{array}{l}\text { Oil yield } \\
\left(\mathrm{kg} \mathrm{ha}^{-1}\right)\end{array}$} \\
\hline & Grain yield & Stalk yield & & \\
\hline $\mathbf{T}_{1}$ & 2.65 & 3.89 & 39.2 & 1039.4 \\
\hline $\mathbf{T}_{2}$ & 1.83 & 2.67 & 38.6 & 704.6 \\
\hline $\mathbf{T}_{3}$ & 2.14 & 3.14 & 38.8 & 829.9 \\
\hline $\mathbf{T}_{4}$ & 2.36 & 3.45 & 38.8 & 913.2 \\
\hline $\mathbf{T}_{5}$ & 2.00 & 2.92 & 39.6 & 788.7 \\
\hline $\mathbf{T}_{6}$ & 3.08 & 4.51 & 39.0 & 1200.7 \\
\hline $\mathbf{T}_{7}$ & 3.20 & 4.70 & 40.3 & 1288.4 \\
\hline $\mathbf{T}_{8}$ & 2.84 & 4.17 & 39.7 & 1127.7 \\
\hline $\mathbf{T}_{9}$ & 2.54 & 3.73 & 40.8 & 1037.8 \\
\hline $\mathbf{T}_{10}$ & 3.43 & 4.99 & 40.2 & 1377.3 \\
\hline S. Em \pm & 0.08 & 0.15 & 0.432 & 31.83 \\
\hline C. D. at $5 \%$ & 0.23 & 0.44 & 1.3 & 94.6 \\
\hline CV (\%) & 5.3 & 6.8 & 1.9 & 5.3 \\
\hline
\end{tabular}

$\mathrm{T}_{1}$ : Irrigation with fresh water $+\mathrm{RDF}$ without gypsum

$\mathrm{T}_{2}$ : Irrigation with beverage industry effluent $+\mathrm{RDF}$ without gypsum

$\mathrm{T}_{3}$ : Alternate irrigation with fresh water and beverage industry effluent + RDF without gypsum

$\mathrm{T}_{4}$ : Cycle of 2 irrigations with fresh water +1 irrigation with beverage industry effluent $+\mathrm{RDF}$ without gypsum

$\mathrm{T}_{5}$ : Cycle of 1 irrigation with fresh water +2 irrigations with beverage industry effluent + RDF without gypsum

FYM@ $7.5 \mathrm{tha}^{-1}$ and borax @ $10 \mathrm{~kg} \mathrm{ha}^{-1}$ common for all the treatments
$\mathrm{T}_{6}$ : Irrigation with fresh water $+\mathrm{RDF}+$ gypsum

$\mathrm{T}_{7}$ : Irrigation with beverage industry effluent $+\mathrm{RDF}+$ gypsum

$\mathrm{T}_{8}$ : Alternate irrigation with fresh water and beverage industry effluent $+\mathrm{RDF}+$ gypsum

$\mathrm{T}_{9}$ : Cycle of 2 irrigations with fresh water +1 irrigation with beverage industry effluent $+\mathrm{RDF}+$ gypsum

$\mathrm{T}_{10}$ : Cycle of 1 irrigation with fresh water +2 irrigations with beverage industry effluent $+\mathrm{RDF}+$ gypsum 
Table.6 Effect of beverage industry effluent irrigation on different fatty acid content of sunflower oil

\begin{tabular}{|c|c|c|c|c|}
\hline \multirow{2}{*}{ Treatments } & Palmitic acid & Stearic acid & Oleic aicd & Linoleic acid \\
\hline & \multicolumn{4}{|c|}{$(\%)$} \\
\hline $\mathbf{T}_{1}$ & 5.68 & 3.11 & 44.7 & 46.5 \\
\hline $\mathbf{T}_{2}$ & 5.98 & 3.43 & 44.5 & 46.1 \\
\hline $\mathbf{T}_{3}$ & 6.02 & 3.48 & 37.8 & 52.7 \\
\hline $\mathbf{T}_{4}$ & 6.33 & 2.88 & 39.8 & 50.7 \\
\hline $\mathbf{T}_{5}$ & 5.66 & 2.98 & 46.3 & 45.1 \\
\hline $\mathbf{T}_{6}$ & 5.52 & 3.12 & 48.3 & 43.1 \\
\hline $\mathbf{T}_{7}$ & 5.39 & 3.62 & 47.8 & 43.2 \\
\hline $\mathbf{T}_{8}$ & 5.45 & 3.31 & 50.4 & 40.8 \\
\hline $\mathbf{T}_{9}$ & 5.93 & 3.02 & 44.0 & 47.0 \\
\hline $\mathbf{T}_{10}$ & 6.79 & 2.97 & 42.0 & 48.3 \\
\hline S. Em \pm & 0.29 & 0.19 & 3.5 & 3.3 \\
\hline C. D. at $5 \%$ & NS & $\mathbf{N S}$ & NS & NS \\
\hline CV (\%) & 8.5 & 10.3 & 13.5 & 12.4 \\
\hline
\end{tabular}

\section{Legend:}

$\mathrm{T}_{1}$ : Irrigation with fresh water $+\mathrm{RDF}$ without gypsum

$\mathrm{T}_{2}$ : Irrigation with beverage industry effluent $+\mathrm{RDF}$ without gypsum

$\mathrm{T}_{3}$ : Alternate irrigation with fresh water and beverage industry effluent + RDF without gypsum

$\mathrm{T}_{4}$ : Cycle of 2 irrigations with fresh water +1 irrigation with beverage industry effluent $+\mathrm{RDF}$ without gypsum

$\mathrm{T}_{5}$ : Cycle of 1 irrigation with fresh water +2 irrigations with beverage industry effluent + RDF without gypsum

FYM@ $9.5 \mathrm{tha}^{-1}$ and borax @ $10 \mathrm{~kg} \mathrm{ha}^{-1}$ common for all the treatments
$\mathrm{T}_{6}$ : Irrigation with fresh water $+\mathrm{RDF}+$ gypsum

$\mathrm{T}_{7}$ : Irrigation with beverage industry effluent $+\mathrm{RDF}+$ gypsum

$\mathrm{T}_{8}$ : Alternate irrigation with fresh water and beverage industry effluent $+\mathrm{RDF}+$ gypsum

$\mathrm{T}_{9}$ : Cycle of 2 irrigations with fresh water +1 irrigation with beverage industry effluent $+\mathrm{RDF}+$ gypsum

$\mathrm{T}_{10}$ : Cycle of 1 irrigation with fresh water +2 irrigations with beverage industry effluent $+\mathrm{RDF}+$ gypsum 
Higher grain and stalk yield in sunflower could be attributed to better total uptake of essential nutrients and its translocation to economic parts as well as improvement in yield attributing characters like total dry matter, head weight, kernel weight per head, numberof grains per head, grain filling per cent, test weight and volume weight. These results are in conformity with the findings of Parameswari (2009). Gypsum had significant effect in increasing the yield of the crop by reducing the effect of sodium on crop growth

Significantly lower grain yield and stalk yield (1.83 and $2.67 \mathrm{t} \mathrm{ha}^{-1}$, respectively) was recorded in the treatment receiving irrigation with beverage industry effluent + RDF without gypsum $\left(\mathrm{T}_{2}\right)$ which may be attributed to accumulation of salts in the root zone and the presence of sodium and chlorides in irrigation water which are absorbed by plants and accumulate in the leaves. These results are in agreement with findings of Mohamedin et al., (2006) and Parameswari (2009).

\section{Quality of sunflower crop}

Oil content and oil yield increased with increase in seed yield and increased $S$ application rates. This might be attributed to the application sulphur which helped in conversion of carbohydrates to oil (Chopra and Kanwar, 1966) and it also played an important role in fatty acid synthesis by converting acetyl Co-A to malonys Co-A. This might be one of the reasons for increased the oil content of sunflower with sulphur application (Padma et al., 2001).

Fatty acids such as palmitic, stearic, oleic and linoleic acid did not differ significantly due to beverage industry effluent irrigation. There was no deleterious effect of the beverage industry effluent on the quality of sunflower oil due to beverage industry effluent. Day et al., (1982) reported that wheat grain quality was not affected by sewage effluent irrigation. Similar observations were reported by Mohan Singh et al., (1993), Babu et al., (1996) and Sharma et al., (2011).

In conclusion, based on the results of field trial, it can be concluded that, sunflower crop performed well under beverage industry effluent irrigation in presence of gypsum. The continuous use of beverage industry effluent for several years may lead to a salinity buildup, as well as contribute to the deterioration of soil quality and results in lower growth, yield and quality of crops. But in Begur, Nelamangala region due to the even distribution of rain, one season crop might be under rainfed condition which might dilute the pollutants and be utilized during the next cropping season. This problem could be effectively managed by the use of gypsum. However, long term field experiments in different agro-climatic zones involving use of different amendments are needed for confirmatory results on this regard.

\section{Acknowledgement}

I am extremely great full to Pepsico Pvt. Ltd., and its staff members for their precious support in successful completion my field experiments at Nelamangalataluk, Bengaluru. I express my sincere gratitude to University of Agricultural Sciences, Bangalore for all the facility.

\section{References}

Ahmad, R. and Jabeen, N., 2009, Demonstration of growth improvement in sunflower (Helianthus annuus L.) by the use of organic fertilizers under saline conditions. Pakistan J. Bot., 41(3): 1373-1384.

Anonymous, 2010, Agricultural statistics at a glance, http:// agricoop.nic.in.

Anonymous, 2012, Ministry of Agriculture, Government of India, http/India stat.dom.

Babu, R. S., Saralabai, V. C., Muralidharan, K. S. and Vivekanandan, M., 1996, Foliar 
application of distillery spent wash as a liquid fertilizer for betterment of growth of Sorghum vulgare and Cajanus cajan. App. Biochem. \& Biotech., 59: 87-91.

Basavalingaiah, Bhaskar, S., Girisha, H. C. and Srinivasamurthy, C. A., 2009a, Utilization of coffee pulp effluent as a source of irrigation on growth, yield, quality of baby corn and chemical properties of soil. National Seminar on Sustainable Waste Management, Mangalore, pp. 52.

Chopra, S. L. and Kanwar, J. S., 1966, Effect of sulphur fertilizers on chemical composition and nutrient uptake by legumes. J. Indian Soc. Soil Sci., 28(3):361-365.

Day, A. D. Swingle, R. S., Tucker, T. C. and Cluff, C. B., 1982, Alfalfa hay grown with municipal waste water and pump water. $J$. Envt. Qlt., 11: 23-24.

Dhananjaya, B. N., 2005, Studies on the effect of treated and untreated coffee pulp effluent on crop growth and soil properties. Ph.D. Thesis, submitted to University of Agricultural Sciences., Bangalore, India.

Imayavarambani, V., Thanunathan, K. and Singaravel, R., 2002, Studies on the influence of integrated nutrient management on growth, yield parameters and seed yield of sesame. Crop Res., 24: 309-313

Mohamedin, A. A. M., Abd el-kader and Badran, N. M., 2006, Response of sunflower (Helianthus annuus L.) to plants salt stress under different water table depths. J. Appl. Sci. Res., 2(12): 1175-1184.

Padma, B., Jagadeshwar, K. and Bharati, M., 2001, Improvement of seed yield and quality through nutrient management in sunflower (Helianthus annuus L.). $J$. Oilseeds Res., 18(1): 48-50.

Parameswari, E., 2009, Impact of agricultural drainage water on crops under sequential biological concentration system and use of nanoparticles for wastewater treatment. Ph.D., thesis, submitted to Tamil Nadu Agricultural University, Coimbatore.

Qadir, M. and Schubert, S., 2002, Degradation processes and nutrient constraints in sodic soils. Land Degradation and Development, 13: 275-294.

Reddy, M. D. and Kumar, K. A., 1996, Performance of sunflower at different irrigation and nitrogen levels during rabi in red chalka soils. J. Oilseeds Res., 13(2): 187-191.

Sharma, N. K., Goswami Bhakti, Gajjar Bijal, Jain Chirag, Soni Deepak and Patel Krishna., 2011, Utilization of Amul Dairy effluent for agriculture practices. Int. J. Envt. sci., 2(1).

Ujjinaiah, U. S., Thimmegowda, S., Sridhara, S. and Prasad, T. G., 1995, Effect of moisture, plant population and fertilizers level on yield of sunflower. Helia, 18: 77-82.

Vaiyapuri, V., Ravi Kumar, C., Sriramachandrasekharan, M. V. and Ravichandran, M., 2004, Effect of sulphur on the growth, yield, quality and nutrient uptake of sunflower. J. Inter Academicia, 8(3): 371-376.

Vijay Krishna, N., 2005, Effect of coffee pulp effluent on growth, yield and quality of rice, M.Sc. (Agri.) Thesis, submitted to University of Agricultural Sciences., Bangalore. India.

Yadav, H. K., Thomas, T. and Khajuria, V., 2010, Effect of different levels of sulphur and biofertilizer on the yield of Indian mustard (Brassica juncea L.) and soil properties. $J$. Agril. Phy., 10: 61-65.

\section{How to cite this article:}

Punith Raj, T.S., C.A. Srinivasamurthy, S. Bhaskar and Prabhudev Dhumgond. 2017. Effect of Beverage Industry Effluent Irrigation Growth, Yield and Quality of Sunflower. Int.J.Curr.Microbiol.App.Sci. 6(4): 2372-2384. doi: https://doi.org/10.20546/ijcmas.2017.604.277 